\title{
CAN CONGRESS PLAY A ROLE IN REMEDYING DYSFUnCTIONAL POLITICAl PARTISANSHIP?
}

\author{
MARK D. ROSEN ${ }^{*}$
}

\section{INTRODUCTION}

A recent situs of deep partisan contestation, and likely a contributing cause of dysfunctional partisanship, is what might be called the "rules-of-the-road" that operationalize our representative democracy-for example the rules governing voter eligibility, how votes are aggregated for purposes of selecting representatives, and how political campaigns are funded. ${ }^{1}$ Controversies concerning voter identification requirements, racial and political gerrymandering, and campaign finance laws have been sharply divisive along partisan lines. ${ }^{2}$ And how these matters are resolved-who can and cannot vote, how district lines are drawn, and how campaigns are funded-influences what kind of candidates are (and are not) elected to public office, and likely affects the degree of political polarization among elected officials. ${ }^{3}$

The Constitution vests virtually all initial power for establishing the rules-ofthe-road in the states, but grants Congress the power to displace those state rules through the Time, Place, and Manner Clause ${ }^{4}$ and several other provisions. ${ }^{5}$ Because Congress has not exercised these powers much, most of today's rules-ofthe-road are state law. ${ }^{6}$ For example, state law is the primary source of registration requirements for both federal and state elections. ${ }^{7}$ In addition, states draw the district lines for both the House of Representatives and for state legislative houses. ${ }^{8}$ One important exception to state law dominance regarding the

* Professor, IIT Chicago-Kent College of Law (mrosen1@kentlaw.iit.edu). I received very helpful comments from my colleagues at an early stage workshop at Chicago-Kent. This Article is a revised version of the presentation given during the Indiana Law Review Symposium held on November 6, 2015 entitled Partisan Conflict, Political Structure, and Culture.

1. Mark D. Rosen, The Structural Constitutional Principle of Republican Legitimacy, 54 WM. \& MARY L. REV. 371, 376-77; 428 (2012).

2. $I d$.

3. Id; see also David DAley, RAtF**Ked: The True Story Behind the Secret Plan to STEAL AMERICA's DEMOCRACY (2016) (arguing that the rise of political partisanship is due in part to increasingly effective political gerrymanders).

4. Ex parte Yarbrough (The Ku Klux Cases), 110 U.S. 651, 659-61(1884).

5. See infra Part I. Other sources include the Guarantee Clause (to govern state elections) and Section Five of the Fourteenth Amendment (insofar as state rules-of-the-road threaten equal protection and incorporated First Amendment protections), as well as the Necessary and Proper Clause, so as to implement the structural constitutional principle of republican legitimacy. Id.

6. Rosen, supra note 1 , at 378 .

7. Elections \& Voting, White House, https://www.whitehouse.gov/1600/elections-andvoting [https://perma.cc/VJC7-2PUJ] (last visited Oct. 15, 2016).

8. Who Draws the Lines?, LoY. L. ScH., L.A., http://redistricting.lls.edu/who.php [https://perma.cc/W7YP-8C2D] (last visited Oct. 15, 2016).

http://doi.org/10.18060/4806.1138 
rules-of-the-road of federal elections is campaign finance, which is substantially governed by federal law. ${ }^{9}$

Until now, those dissatisfied with the rules-of-the-road have mainly directed their disgruntlements to courts, bringing constitutional challenges grounded in equal protection and free speech, as well as statutory claims relying primarily on the Voting Rights Act. ${ }^{10}$ While the Voting Rights Act has been spectacularly successful in expanding the franchise ${ }^{11}$ lawsuits have had far less success in relation to the other rules-of-the-road. ${ }^{12}$

In past work, I have suggested two pivots to improve representative democracy's rules-of-the-road. ${ }^{13}$ The first is substantive, and it concerns the nature of the constitutional interest at stake. ${ }^{14}$ Until now, courts have understood that problematic rules-of-the-road can threaten individual rights protected by the Equal Protection and Free Speech Clauses, but they have overlooked a structural constitutional principle of potentially greater import that might be called "Republican Legitimacy."15 Republican Legitimacy encompasses the preconditions for the republican forms of government that the Constitution establishes for the federal government and guarantees to the states to operate legitimately and successfully. ${ }^{16}$ Recognizing the structural constitutional principle at stake is crucial because individual rights cannot be relied upon to protect structural interests, for two main reasons. ${ }^{17}$ Rights-focused analysis readily overlooks the structural harm. ${ }^{18}$ Moreover, several constitutional sub-doctrines that may be sensible in relation to individual rights are inapposite to structural constitutional interests, and in fact have blocked effective judicial review of structural harms to Republican Legitimacy. ${ }^{19}$

The second pivot is institutional: rather than turning only to courts, we must rely increasingly on legislators, principally though not exclusively Congress. ${ }^{20}$ Legislatures must be relied upon partly because courts have found it difficult to develop judicially administrable standards to police the rules-of-the-road. ${ }^{21}$ To be sure, courts' difficulties are partly an artifact of their having misconceived the nature of the constitutional harm: their having considered only individual rights,

9. Federal Campaign Finance Laws, Fed. EleCtion Commission, http://www.fec.gov/law/ feca/feca.shtml [https://perma.cc/GG2E-ESQJ] (last visited Oct. 15, 2016).

10. Rosen, supra note 1 , at 421 .

11. Through not only lawsuits, but also federal administrative action.

12. See Rosen, supra note 1 , at 428-51.

13. Id. at $387-93$.

14. Id. at $386-93$.

15. Id. at 381-93.

16. $I d$. at 377 . For a pithy elaboration, see text accompanying notes 92-99.

17. Id. at $378,421-28$.

18. Id.

19. Id. at 421-32.

20. Id. at 381 .

21. See id. at 450-51. This can most clearly be seen in the case of political gerrymandering. For a discussion, see Rosen, supra note 1, at 436-41. 
overlooking harm to the structural constitutional principle of Republican Legitimacy. ${ }^{22}$ While correcting that misconception should facilitate judicial review, the judicial role still would not be simple because political considerations inevitably, and appropriately, play an important role in selecting the rules-of-theroad. ${ }^{23}$ Politics' pervasive persistence is why legislatures must play a central role in choosing the rules-of-the-road. At most, courts can play a checking function. ${ }^{24}$

My insistence that Congress be relied on to improve representative democracy's rules-of-the-road may be criticized as a "self-defeating proposal" that asks legislators to overcome the very problems I am trying to remedy. ${ }^{25}$ Simply stated, insofar as legislators created the problematic rules-of-the-road in the first place, ${ }^{26}$ how can they be relied on to clean up their mess?

This is a serious objection. But two separate considerations suggest that this Self-Defeating Proposal Objection ("the Objection") may be inapt and, at the very least, is not definitive. First, until now, legislators have not appreciated that the rules-of-the-road implicate the Constitution. ${ }^{27}$ This must, and can, change. ${ }^{28}$ The Objection thus presupposes that legislators will not take seriously their oaths to uphold the Constitution after they realize that Republican Legitimacy's security depends upon the rules-of-the-road within their control. ${ }^{29}$ The proposition that legislators will willfully disregard their constitutional obligations is not axiomatic, and indeed may be mistaken. ${ }^{30}$

Second, the Self-Defeating Proposal Objection blurs the distinction between state legislators and Congress. ${ }^{31}$ Virtually all of today's problematic rules-of-theroad are state law. ${ }^{32}$ Congress, however, is different from state legislatures in ways that may make it less susceptible to the malfeasances that have occurred at the state level. ${ }^{33}$ For example, Congress's members may, on average, be more

22. See Rosen, supra note 1, at 428-52 (showing how the structural constitutional principle of Republican Legitimacy facilitates analysis of voter identification laws, partisan gerrymandering, and campaign finance law).

23. Id. at 453 .

24. Id.

25. See Adrian Vermeule, Self-Defeating Proposals: Ackerman on Emergency Powers, 75 FordHAM L. REV. 631, 637-40 (2006).

26. See, e.g., Rosen, supra note 1, at 375 (quoting the New York State Senate president who said, "[W]e are going to draw the lines so that Republicans will be in oblivion in the state of New York for the next 20 years," and the democratic chairman of an Illinois county districting plan who said, "We are going to shove [the district map] up your $\mathrm{f}^{* *}$ king ass and you are going to like it, and I'll $\mathrm{f}^{* *} \mathrm{k}$ any Republican I can").

27. Id.

28. My scholarship has taken aim at this misperception with the hope of making legislators aware of their constitutional responsibilities. See Rosen, supra note 1, at 377-78.

29. Id. at $372,454$.

30. Id. at 388 .

31. Id. at 454 .

32. Id.

33. Id. 
competent than those who serve in state legislatures. This is because state legislatures frequently serve as Congress's junior varsity, and also because each member of Congress is selected from a larger population. Additionally, the greater media attention Congress garners may subject it to greater political accountability that inclines it to act more responsibly than state legislatures.

This Article develops several components of a response to the Self-Defeating Proposal Objection. ${ }^{34}$ First, it shows Congress's powers to enact representative democracy's rules-of-the-road. ${ }^{35}$ Second, the Article argues that selecting the rules-of-the-road substantially belongs to the domain of constitutional decisionmaking, insofar as problematic rules threaten the Constitution by undermining the legitimacy of our representative democracy's laws. ${ }^{36}$ Third, the Article raises a question that follows from the first two points, and that takes direct aim at the Self-Defeating Proposal Objection: might Congress be more apt to act responsibly upon realizing that ensuring appropriate rules-of-the-road belongs to the domain of constitutional decisionmaking? $?^{37}$

Although proponents of the Self-Defeating Proposal Objection might scoff at this suggestion, it would be premature to conclude that Congress is incapable of functioning as a responsible constitutional decisionmaker. This conclusion is based partly on history: David Currie's extraordinary series of books, The Constitution in Congress, depicts a sustained era during which Congress appears to have engaged in serious and responsible constitutional decisionmaking. ${ }^{38}$ Resisting the cynicism that grounds the Objection is necessary if we are to avoid the error of confusing what is for what must be. Although the proposition that Congress can serve as a responsible constitutional decisionmaker may strike many today as naively fanciful, ${ }^{39}$ present day deficiencies may be correctible

34. This Article does not even begin to consider what types of substantive fixes Congress might enact. That is the subject of a work-in-progress of mine. See generally Mark D. Rosen, Implementing Republican Legitimacy (work-in-progress on file with author). Widespread cynicism of Congress has led me to address motivational questions before exploring specific proposals.

35. See infra Part I. To be clear, this does not mean that states are without power to enact the rules-of-the-road but that Congress also has such powers. Here, as elsewhere, there is an overlap of federal and state legislative powers. See generally Mark D. Rosen, From Exclusivity to Concurrence, 94 MinN. L. REv. 1051 (2010).

36. See infra Part II. This second point applies to whichever institution, federal or state, enacts the rules-of-the-road.

37. See infra Part III.

38. See generally David P. Currie, The Constitution in Congress: The Federalist Period, 1789-1801 (1997); David P. Currie, The Constitution in Congress: The Jeffersonians, 1801-1829 (2001); David P. Currie, The Constitution in Congress: Democrats AND Whigs, 1829-1861 (2005); DAvid P. CurRie, The Constitution In Congress: DESCENT INTO THE MAELSTROM, 1829-1861 (2007). I do not further explore this historical point in this Article.

39. Paul Brest, the scholar long associated with taking seriously Congress's role as a constitutional decisionmaker, now voices substantial skepticism, though he ultimately concludes, "It is an open question whether the contemporary Congress could become a responsible 
rather than endemic. A lacuna in professional norms may be among the causes. ${ }^{40}$ There is little, if any, sense among today's legislators that a special set of norms, different from those at play in ordinary politics, properly operates during constitutional decisionmaking. ${ }^{41}$ A work-in-progress of mine takes aim at this modern sensibility, arguing that special behavioral norms properly apply to Congress when it engages in constitutional decisionmaking. ${ }^{42}$ These norms would increase the likelihood of Congress responsibly engaging in constitutional decisionmaking, further defanging the Self-Defeating Proposal Objection. ${ }^{43}$

This Article's argument comes in three parts. Part I shows that Congress has substantial power to enact the rules-of-the-road for both federal and state elections. Part II argues that deciding whether to enact federal rules-of-the-road, and if so, what to enact - the whether and what questions in relation to the rulesof-the-road - are substantially influenced by constitutional considerations and, for that reason, belong to the domain of constitutional decisionmaking. Part III suggests the very fact that the whether and what questions belong to the domain of constitutional decisionmaking may increase the likelihood Congress will deal with the rules-of-the-road in a responsible manner, thereby countering the SelfDefeating Proposal Objection.

\section{Congress's Power to Regulate Representative Democracy'S RULES-OF-THE-ROAD}

Congress's power concerning representative democracy's rules-of-the-road must be separately analyzed in relation to the federal and state governments.

\section{A. Federal Elections}

There are three sources of congressional power to enact the rules-of-the-road in relation to the federal government: (1) the "Times, Places and Manner"

constitutional decisionmaker." See Paul Brest, Congress as Constitutional Decisionmaker and its Power to Counter Judicial Doctrine, 21 GA. L. REV. 57, 98-101 (1986). Similarly, the late congressman and federal appellate judge Abner Mikva thought Congress "has for the most part . .. left constitutional judgments to the judiciary" and that Congress's "willingness to step aside has been due in part to institutional pressures and in part to political convenience." Abner Mikva, How Well Does Congress Support and Defend the Constitution?, 61 N.C. L. REv. 587, 588 (1983).

40. For a discussion of another plausible cause, see Mark Tushnet, Some Notes on Congressional Capacity to Interpret the Constitution, 89 B.U.L.REv. 499, 499-500; 504-07 (2009) (discussing the phenomenon of "judicial overhang").

41. Mark D. Rosen, The Special Norms Thesis: Why Congress' Constitutional Decisionmaking Should be Disciplined by More Than the Usual Norms of Politics 2 (work-inprogress on file with author).

42. See generally id. It bears mention that the Special Norms Thesis has implications not just for the rules-of-the-road, but for the entire gamut of Congress' constitutional decisions.

43. Id. at 58-60. 
Clause, ${ }^{44}(2)$ the "Chusing of Electors" Clause, ${ }^{45}$ and (3) the Necessary and Proper Clause. ${ }^{46}$

The Court consistently has ruled that Congress has broad legislative authority under the "Times, Places, and Manner" Clause ("TPM Clause"). "Congress has plenary and paramount jurisdiction over the whole subject" of the times, places, and manner of congressional elections. ${ }^{48}$ Congress has authority to

provide a complete code for congressional elections, not only as to times and places, but in relation to notices, registration, supervision of voting, protection of voters, prevention of fraud and corrupt practices, counting of votes, duties of inspectors and canvassers, and making and publication of election returns; in short, to enact the numerous requirements as to procedure and safeguards which experience shows are necessary in order to enforce the fundamental right involved. ${ }^{49}$

Although the TPM Clause speaks only of "[e]lections," the Court has held that Congress's power extends to primaries. ${ }^{50}$ Pursuant to the "Chusing the Electors" Clause, Congress's power in relation to presidential elections appears to be coextensive with its power under the TPM Clause to regulate congressional elections. ${ }^{51}$ The Court has consistently upheld regulations of both congressional and presidential elections by only analyzing Congress's TPM Clause powers. ${ }^{52}$

The TPM and "Chusing of Electors" Clauses likely give Congress all the power it needs to regulate the rules-of-the-road of federal elections. ${ }^{53}$ If they did not, any gaps in congressional power would be filled by the Necessary and Proper Clause. ${ }^{54}$ The Constitution creates an essentially republican federal government, insofar as the President and members of Congress are selected by the People. ${ }^{55}$ The Necessary and Proper Clause's grant to "[carry] into Execution the . . . Powers vested by this Constitution in the Government of the United States."

44. Rosen, supra note 34 , at 20.

45. Id.

46. $I d$.

47. Id.

48. Ex parte Siebold, 100 U.S. 371, 388 (1879) (upholding a challenge to the 1870 Enforcement Act).

49. Smiley v. Holm, 285 U.S. 355, 366 (1932). For an extensive list of Supreme Court cases upholding various federal regulations, see Voting Rights Coalition v. Wilson, 60 F.3d 1411, 1414 (9th Cir. 1995).

50. United States v. Classic, 313 U.S. 299, 317 (1941).

51. Burroughs v. United States, 290 U.S. 534, 544-46 (1934).

52. Id. at 544-48 (citing Ex parte Yarborough, 110 U.S. 651, 657-58 (1884)).

53. See Rosen, supra note 34 , at 20.

54. Id. at 22 .

55. See Rosen, supra note 1 , at 381-82.

56. U.S. Const. art. I, $\S 8$, cl. 18. For a list of cases where the Court relied on the Necessary and Proper Clause to uphold "appropriate legislation to safeguard the right of choice by the people of representatives in Congress," see United States v. Classic, 313 U.S. 299, 319-21 (1941). 
includes the power to operationalize the federal representative democracy the Constitution creates. ${ }^{57}$ Because operationalizing representative democracy is precisely what the rules-of-the-road do, the Necessary and Proper Clause would provide Congress any and all remaining powers to enact the rules-of-the-road for federal elections not granted by the TPM and "Chusing of Electors" Clauses. ${ }^{58}$

\section{B. State Elections}

Congress's ability to enact the rules-of-the-road for state elections is less certain than its power to regulate federal elections, on account of both the source of its power and federalism-based limits to that power. Even so, Congress likely has substantial powers to create the rules-of-the-road for state elections.

1. Congress's Power in Relation to State Rules-of-the-Road.-There is a direct textual source for congressional power to enact rules-of-the-road for state elections. The Guarantee Clause provides " $[t]$ he United States shall guarantee to every State in this Union a Republican Form of Government," 59 and long has been understood by the Supreme Court to be "primarily a legislative power [that] resides in Congress. ${ }^{\circ 0}$ On the other hand, Congress has relied on its Guarantee Clause powers only a few times, ${ }^{61}$ and has never relied on it to enact a state ruleof-the-road. ${ }^{62}$

Yet even without direct precedent, congressional power to regulate the states' rules-of-the-road seems to rest on strong grounds. Congress's power to guarantee representative governments in the states plausibly includes the substitution of federal rules for state rules-of-the-road that threaten the states' republican forms of government by undermining their legitimacy. And Congress's power under the Guarantee Clause extends to prophylactic rules-of-the-road, especially because

57. See U.S. Const. art. I, $\S 8$, cl. 18 .

58. Rosen, supra note 35 , at 22.

59. U.S. Const. art. IV, § 4.

60. Texas v. White, 74 U.S. 700, 730 (1868); see also South Carolina v. United States, 199 U.S. 437, 454 (1905).

61. Congress relied on the Guarantee Clause when enacting the Reconstruction Acts, which created provisional governments in the secessionist states following the Civil War. See Reconstruction Acts, ch. 153, 14 Stat. 428 (1867); Adam H. Kurland, The Guarantee Clause as a Basis for Federal Prosecutions of State and Local Officials, 62 S. CAL. L. REV. 367, 438 \& nn. 26162 (1989) (collecting sources demonstrating the federal government's reliance on the Guarantee Clause when enacting and defending the constitutionality of the Reconstruction Acts). Congress also used its Guarantee Clause powers when deciding to accept new states into the Union. See, e.g., Act of Sept. 9, 1850, ch. 50, 9 Stat. 452 (accepting California); Act of May 4, 1858, ch. 26, 11 Stat. 269 (accepting Kansas).

62. See supra note 61. In the other direction, the Reconstruction Congress's reliance on the Guarantee Clause to create provisional governments in secessionist states might ground an $a$ fortiori argument for congressional power to (only) enact rules-of-the-road for the governments the states themselves created. Although such an argument is not implausible, the post-Civil War era's exigencies surely make the Reconstruction Acts an uncertain exemplar. 
Congress reasonably could conclude that many of today's rules-of-the-road threaten the legitimacy of representative government. ${ }^{63}$ Prophylactic powers are naturally grounded in that clause's language of "guarantee," which is readily construed to authorize proactive steps to preempt possible harm to republicanism.

Congress's power to enact some rules-of-the-road for state elections also may be grounded in Section Five of the Fourteenth Amendment. ${ }^{64}$ Contemporary case law understands that state-made rules-of-the-road may threaten the equal protection and free speech rights secured by Section One of the Fourteenth Amendment. ${ }^{65}$ From this it follows that Congress has legislative power under Section Five to enact those rules-of-the road that would help enforce these Fourteenth Amendment rights. And congressional power under Section Five extends to prophylactic enactments, as the Court recently reconfirmed. ${ }^{66}$

But there are two reasons why Section Five cannot be the exclusive source for all the state rules-of-the-road that might be appropriate for Congress to enact. The first is the Supreme Court's recent restrictions of Congress's Section Five powers in Boerne v. Flores ${ }^{67}$ and its progeny. Boerne's requirement that Congress legislate only if there is already a pattern of state infringement ${ }^{68}$ might unduly restrict Congress's ability to act prophylactically, notwithstanding that case's holding that Congress's Section Five powers authorize prophylactic legislation. ${ }^{69}$ By way of contrast, the power to guarantee a republican form of government

63. As regards gerrymandering, see DALEY, supra note 3; Sam Hirsch, The United States House of Unrepresentatives: What Went Wrong in the Latest Round of Congressional Redistricting, 2 ELECTION L.J. 179 (2003) (providing exhaustive analysis of gerrymandering of congressional districts). For a discussion of suppression-oriented voter identification requirements, see SPENCER Overton, Stealing Democracy: The New Politics of Voter Suppression 148-67 (2006).

64. See U.S. Const. amend. XIV, § 5 ("The Congress shall have power to enforce, by appropriate legislation, the provisions of this article.").

65. For example, although his opinion declared political gerrymandering non-justiciable, Justice Scalia acknowledged that "severe" political gerrymandering may be unconstitutional. See Vieth v. Jubelirer, 541 U.S. 267, 292 (2004) (agreeing with Justice Stevens' argument as to "the incompatibility of severe partisan gerrymanders with democratic principles" and clarifying that " $[t]$ he issue we have discussed is not whether severe partisan gerrymanders violate the Constitution, but whether it is for the courts to say when a violation has occurred, and to design a remedy"). Likewise, the Court understands that voter registration requirements may trigger equal protection concerns. See Rosen, supra note 1, at 431-34 (explaining that the Crawford decision rejected the challenge to Indiana's registration requirements for being prematurely brought, not because registration requirements do not implicate the Constitution).

66. See Boerne v. Flores, 521 U.S. 507, 518-19 (1997). But see infra note 73 and accompanying text.

67. 521 U.S. at 536.

68. See id. at 531-35.

69. See id. at 535-56; see also Fla. Prepaid Postsecondary Educ. Expense Bd. v. Coll. Sav. Bank, 527 U.S. 627, 660-61 (1999) (Stevens, J., dissenting) (arguing “The Court's opinion today threatens to read Congress' power to pass prophylactic legislation out of [Section Five] altogether ..."). 
more readily encompasses prophylactic enactments, insofar as "guarantee" naturally includes proactive steps taken before any harms materialize.

Second, Section Five is substantively inadequate. While Section Five authorizes legislation to enforce the individual rights protected by Section One, ${ }^{70}$ some rules-of-the-road threaten constitutional interests that do not fall within Section One. For example, the constitutional interest that all states have a republican form of government is not reducible to the individual rights protected by Section One; republicanism is a structural constitutional interest that is conceptually distinct from, and whose contents do not perfectly overlap with, the fundamentally individual rights protected by equal protection and free speech. ${ }^{71}$ Constitutional interests derived from republicanism, but not encompassed within individual rights, accordingly cannot be protected by legislation enacted under Section Five. Insofar as the rules-of-the-road implicate republican interests not covered by individual rights, Section Five cannot serve as the exclusive source for federally enacted rules-of-the-road.

2. Federalism Limits on Congressional Rules-of-the-Road.-Unlike federal elections, Congress's power to enact rules-of-the-road for state elections is limited by federalism considerations. ${ }^{72}$ This is likely true regardless of the constitutional power upon which Congress relied, be it the Guarantee Clause or Section Five of the Fourteenth Amendment. ${ }^{73}$ And the federalism costs of federally-enacted rules-of-the-road for state elections is no mere academic nicety. This is because republicanism does not entail a unique set of rules-of-the-road, but is consistent with many different possibilities. In choosing which rules-of-theroad to select among the set of constitutionally acceptable options, a state legitimately might take account of such considerations as its own history, its economic and ethnic demographics, and the eminently political views it might have as to how citizens' preferences should be aggregated for purposes of selecting the state's policies. Interfering with the states' ability to make such decisions deeply implicates federalism. ${ }^{74}$

70. See U.S. Const. amend. XIV, §5.

71. See Rosen, supra note 1, at 421-28 (arguing that individual rights are distinct from structural protections of republicanism).

72. Rosen, supra note 34 , at 22.

73. An argument might be made that federalism concerns are less forceful vis-à-vis Section Five because it is part of an amendment that reworked the original Constitution's federalism in favor of federal power. $C f$. Seminole Tribe of Fla. v. Florida, 517 U.S. 44, 59 (1996) (holding the Eleventh Amendment's restrictions apply to legislation enacted under Congress's Article I powers but not under Section Five of the Fourteenth Amendment because "the Fourteenth Amendment, by expanding federal power at the expense of state autonomy, had fundamentally altered the balance of state and federal power struck by the Constitution"). I am not persuaded such a distinction should be drawn between the Guarantee Clause and Section Five, though this Article is not the appropriate place to explain why. For an allusion as to why a distinction may not be appropriate, see Rosen, supra note 1, at 403-04 (endorsing Professor Amar's argument that constitutional amendments may shape the way provisions in the original Constitution are understood).

74. Indeed, these decisions may be central to determining whether states are the meaningfully 
That there are federalism-based limits does not mean that congressionallyenacted rules-of-the-road for state elections would be per se unconstitutional. ${ }^{75}$ But at the very least federalism demands that before enacting any state rules-ofthe-road, Congress must carefully consider whether it is necessary, in some meaningful sense, to do so. Without purporting to fully specify what this would mean, it at least would entail a deliberate and informed judgment that the abovementioned costs to federalism are offset by the risks to republicanism of continuing to allow states to select a particular rule-of-the-road. ${ }^{76}$

\section{Why Selecting the Rules-of-The-Road Belongs Substantially to THE Domain of Constitutional DeCisionMAKING}

Part I argued that Congress has constitutional power to enact many of representative democracy's rules-of-the-road. This Part II argues that whether Congress enacts rules-of-the-road, and what rules it enacts-what I shall refer to as the whether and what questions - are substantially informed by constitutional considerations. Accordingly, the whether and what questions in relation to the rules-of-the-road belong to the domain of constitutional decisionmaking.

\section{A. Avoiding Confusion}

The claim presented in this Part II can be misconstrued in a manner that would make it duplicative of Part I's argument. To head off potential confusion, I will labor to make clear where Part I's argument ends and Part II's begins. That is best done by way of an example.

Imagine that to encourage new vaccines that may save large numbers of lives, Congress considers whether to enact the Lawsuit Relief Act-legislation that would shield drug companies from lawsuits brought by the people who (inevitably) would suffer harmful side-effects from even socially beneficial and properly manufactured vaccines. ${ }^{77}$ The threshold question that Congress should consider is a constitutional one: does it have the power to enact legislation of this sort? If it does, Congress next would have to decide how to trade-off the sideeffect sufferers' interests, on the one hand, against the interests of the drug companies and of the people who stand to benefit from the vaccine, on the other.

empowered sub-federal polities that federalism may presuppose.

75. Rosen, supra note 34 , at 22-23.

76. This is an eminently constitutional judgment insofar as interests of constitutional dimension are on both sides of the ledger. Though this brief Article is not the place to fully explain how the congressional decisionmaking discussed above should be operationalized, it is worth observing that the Court's clear statement rule jurisprudence is a judicial technique for encouraging Congress to give explicit attention to constitutional questions. See William N. Eskridge, Jr. \& Philip P. Frickey, Quasi-Constitutional Law: Clear Statement Rules as Constitutional Lawmaking, 45 VAND. L. REV. 593, 597 (1992) (noting clear statement rules may function so as to "forc[e] the political process to pay attention to the constitutional values at stake").

77. This is not so hypothetical. See National Childhood Vaccine Injury Act, 42 U.S.C. $\S \S$ 300aa-10 to 300aa-34 (2012). 
Determining how to trade-off among these interests turns on facts ${ }^{78}$ and valueladen judgments. ${ }^{79}$ The considerations informing the trade-off are not of constitutional dimension, but belong largely (perhaps exclusively) to the political domain. ${ }^{80}$ Likewise, whether Congress acts at all, or does nothing, is largely (perhaps exclusively) informed by political, not constitutional, considerations. ${ }^{81}$ So although constitutional considerations are not entirely absent-recall the threshold inquiry concerning congressional power to enact such legislation-whether the Lawsuit Relief Act is enacted and, if so, what its substance should be, are determined primarily (perhaps exclusively) by political considerations.

Part I's argument parallels the threshold constitutional decision Congress would have to make before enacting the Lawsuit Relief Act, for it showed Congress's power to enact representative democracy's rules-of-the-road. Part II addresses the considerations that appropriately determine whether Congress should enact rules-of-the-road and, if it does, what rules it should enact. This Part II's claim is that, unlike the Lawsuit Relief Act, the considerations that properly determine whether and what regarding the rules-of-the-road are predominantly of constitutional dimension. Answering the whether and what questions regarding the rules-of-the-road accordingly belongs to the domain of constitutional decisionmaking, something not true of the Lawsuit Relief Act.

Having clarified Part II's claim, now let me establish it. As was true of Part I's analysis, it is necessary to disaggregate state from federal elections.

\section{B. Constitutional Dimensions of State Rules-of-the-Road}

As to the whether question: whether Congress should enact rules-of-the-road for state elections belongs to the constitutional domain on account of the

78. Such as: how many side-effect sufferers are there likely to be? To what extent will vaccine-production be discouraged by allowing their lawsuits to go forward? How beneficial will the vaccine be?

79. Such as: should the vaccine's costs be borne by the unlucky few upon whom they fall or should the costs be shared? If the latter, should compensation be restrained or generous?

80. Constitutional considerations may restrict the range of possible trade-offs. For instance, due process may require some minimum compensation for side-effect sufferers if tort liability is eliminated. But the choice within the range of permissibility is determined by considerations that belong to the domain of the exclusively political.

81. Beyond the consideration mentioned above in note 80 , two other constitutional considerations might inform the whether and what determinations. The first is whether Congress might conclude it has a proactive constitutional obligation to protect citizens' lives even if courts will not judicially enforce any such constitutional right under DeShaney v. Winnebago Count Department of Social Services, 489 U.S. 189, 196, 203 (1989). See generally LAWRENCE G. SAGER, Justice in Plainclothes: A Theory of American Constitutional Practice (2004). Second is the federalism-inflected question of whether this sort of policy should be determined by states rather than the national government. 
Guarantee Clause. ${ }^{82}$ The Clause imposes an affirmative constitutional duty on Congress to ensure state governments are republican in character. ${ }^{83}$ Because the rules-of-the-road are among the determinants of whether a government is republican ${ }^{84}$ problematic rules-of-the-road can threaten republicanism ${ }^{85}$ If there are such problematic rules-of-the-road, Congress has an affirmative duty to act so as to guarantee that the state continues to have a republican form of government. Determining whether state rules-of-the-road undermine republicanism also belongs to the domain of constitutional decisionmaking.

As to the what question: if Congress concludes that some rules-of-the-road threaten a state's republican form of government, the Necessary and Proper Clause affords Congress an array of options, from legislation that pressures states to change problematic rules-of-the-road to enacting substitute rules itself. Deciding which option to exercise is properly informed by constitutional considerations, namely principles of republicanism and federalism. ${ }^{86}$ Should Congress opt to directly enact federal rules, selecting what rules-of-the-road to adopt would be substantially, though not wholly, informed by constitutional considerations. Many possible rules-of-the-road would risk undermining republicanism and, for that reason, should not constitute live options. Determining what potential rules-of-the-road are in-bounds, and which are out-ofbounds, properly belongs to the domain of constitutional decisionmaking.

To be clear, selection of the rules-of-the-road is not guided exclusively by considerations belonging to the constitutional domain. For example, although constitutional considerations properly exclude early voting rules that systematically reduce the votes of an identifiable population, ${ }^{87}$ many important details concerning early voting are informed by sub-constitutional pragmatic considerations (such as cost and likely efficacy).

It might be tempting to hypothesize that political, not constitutional, considerations alone inform the selection among in-bound options. But this may not be true. Some choices among in-bound options may be so central to constituting a polity's character that their selection is best understood as belonging to the constitutional domain. ${ }^{88}$ Although a complete specification of the

82. See Texas v. White, 74 U.S. 700, 730 (1868) (concluding "[T]he power to carry into effect the clause of guaranty is primarily a legislative power, and resides in Congress."), overruled in part on other grounds by Morgan v. United States, 113 U.S. 476 (1885).

83. U.S. CONST. art. IV, $\S 4$.

84. The rules-of-the-road are not the sole determinants of a state's republican character. For example, hereditary succession for governors would disqualify a state as being republican, though they would not properly be characterized as rules-of-the-road.

85. See Rosen, supra note 1 , at 405.

86. See supra text accompanying note 76 .

87. See, e.g., N.C. State Conf. of NAACP v. McCrory, 831 F.3d 204 (4th Cir. 2016) (holding restrictions on early voting violated the Equal Protection Clause of the Fourteenth Amendment and Section 2 of the Voting Rights Act because of the voting law's racially discriminatory effects on African Americans, who disproportionately utilized early voting).

88. For a similar approach, see David A. Super, The Modernization of American Public Law: 
criteria for identifying the constitutional domain must await another day, ${ }^{89}$ the point for present purposes is that constitutional considerations play a more far domineering role in selecting the rules-of-the-road than in the hypothetical Lawsuit Relief Act (and, indeed, in most of the laws that allocate the costs, benefits, and risks of social life).

\section{Constitutional Dimensions of Federal Rules-of-the-Road}

As explained in Part I, though the Time, Place and Manner Clause recognizes, or impliedly grants, state power to establish the rules-of-the-road for federal elections, Congress has the power to displace these state-made rules-ofthe-road with federal rules. ${ }^{90}$ Whether Congress should exercise this power and, if so, what it should enact, are substantially informed by constitutional considerations, and for that reason belong to the domain of constitutional decisionmaking.

As to the whether determination: it is not the Guarantee Clause that accounts for the fact that determining whether there should be federal rules-of-the-road belongs to the constitutional domain, because that clause extends only to state governments. ${ }^{91}$ Rather, determining whether there should be federal rules-of-theroad for federal elections belongs to the constitutional domain on account of the structural principle of Republican Legitimacy. ${ }^{92}$ To briefly summarize, Republican Legitimacy is akin to our constitutional tradition's two other great structural constitutional principles, separation-of-powers and federalism. ${ }^{93}$ Federalism is not textually announced by the Constitution, but is inferred from the fact that the Constitution presupposes states. ${ }^{94}$ Likewise, separation-of-powers is not found in explicit constitutional text, but is inferred from the Constitution's creation of the federal government's three departments. ${ }^{95}$ So too, the

Health Care Reform and Popular Constitutionalism, 66 StAn. L. REV. 873, 879 (2014) (referring to the "constitution of statutes" where "fundamental values ... [are] constitutionalized through statutes”); see also William N. Eskridge Jr. \& John Ferejohn, A Republic of Statutes: The New American Constitution 3-5 (2010).

89. This Article does not purport to provide a definitive definition or taxonomy of the constitutional domain. Nor does this Article take a position as to how the constitutional domain is best identified, i.e., by definition or through a (Wittgenstein-like) case-by-case assessment of what belongs to the constitutional domain. See Mark D. Rosen, Beyond Interpretation: The "Cultural Approach" to Understanding Extra-Formal Change in Religious and Constitutional Law, 2 J.L. Religion \& St. 200, 203 \& n.6 (2013) (explaining Wittgenstein's approach to meaning). A work-inprogress addresses the constitutional domain in greater detail. See Rosen, supra note 41.

90. U.S. Const. art. IV, § 4. And, as argued above, Congress also has power to legislate some state rules-of-the-road under Section Five of the Fourteenth Amendment.

91. See U.S. Const. art. IV, § 4.

92. See Rosen, supra note 1 , at 381-93.

93. Id. at 382-83.

94. Id. at 382-85.

95. Id. at $381-82$. 
Constitution's establishment of an essentially representative federal government ${ }^{96}$ impliedly carries with it a constitutional principle. ${ }^{97}$ As federalism protects the states and separation-of-powers protects the federal government's constitutionally created departments, Republican Legitimacy protects the federal republican government that the Constitution creates. $^{98}$ More specifically, Republican Legitimacy encompasses the necessary preconditions for our nation's republican government to successfully and legitimately operate. ${ }^{99}$

A state's rules-of-the-road for federal elections can undermine the legitimacy of our federal republic's law, threatening Republican Legitimacy. ${ }^{100}$ Congressional inaction in the face of such state-made rules-of-the-road is an abnegation of its power and responsibility to "make all Laws which shall be necessary and proper for carrying into Execution"101 the federal government's republican form of government. ${ }^{102}$ Accordingly, where state-made rules-of-theroad threaten Republican Legitimacy, the whether determination regarding federal rules-of-the-road belongs to the domain of constitutional decisionmaking. ${ }^{103}$

The what determination regarding federal rules-of-the-road also substantially belongs to the domain of constitutional decisionmaking. This is true for most of the reasons discussed above concerning the what determination of state rules-ofthe-road. ${ }^{104}$ Republicanism rules out many conceivable rules-of-the-road. Determining what rules-of-the-road fall within the range of the constitutionally permissible - are in-bounds-belongs to the domain of constitutional decisionmaking. Finally, some choices among constitutionally permissible options may be so central to defining our country's character as to properly fall

96. Of course the original Constitution did not establish a fully republican federal government, insofar as neither the President nor the Senate were directly elected by the People. But over time, by dint of amendments and custom, the federal government has become increasingly republican. For a discussion of this topic, see $i d$.

97. Id. at 385 .

98. See id. at 381-93.

99. In other words, the constitutional text creating a republican federal government presupposes, or gives rise to, the structural constitutional principle of Republican Legitimacy. See id.

100. See id. at 386-93, 429-32 (explaining how unduly strict voter identification laws threaten Republican Legitimacy); see also 436-41 (explaining how partisan gerrymandering threatens Republican Legitimacy).

101. See U.S. Const. art. $1, \S 8$, cl. 18.

102. See Rosen, supra note 41 at 61 .

103. To be clear, the whether determination does not exclusively comprise constitutional considerations. Even where state rules-of-the-road do not threaten Republican Legitimacy, Congress has discretionary authority under the Time, Place and Manner Clause to enact rules-ofthe-road for federal elections.

104. See supra Part II.B. The federalism implications of federally enacted rules-of-the-road for state elections are absent from federal rules for federal elections. 
within the domain of constitutional decisionmaking. ${ }^{105}$

\section{CONCLUSION AND PROLEGOMENON TO FUture Work}

Part I showed that Congress has substantial power under the Constitution to enact representative democracy's rules-of-the-road, and Part II argued that deciding whether and how to exercise this power is substantially informed by constitutional considerations. It follows that Congress's whether and what determinations regarding representative democracy's rules-of-the-road belong substantially to the domain of constitutional decisionmaking.

So we return to the Self-Defeating Proposal Objection, which rejects as implausible the proposition that Congress can be relied upon to remedy problematic rules-of-the-road. ${ }^{106}$ As a result of Parts I and II, we can now see that the Objection succeeds in relation to the rules-of-the-road only if it is conclusively assumed that Congress will not function as a responsible constitutional decisionmaker. ${ }^{107}$

Any such definitive conclusion is unduly pessimistic and, at the very least, not axiomatic. That the whether and what questions in relation to the rules-of-theroad substantially belong to the domain of constitutional decisionmaking on its own may increase the likelihood of responsible congressional action. ${ }^{108} \mathrm{~A}$ workin-progress of mine provides an extensive formal argument as to why Congress should act more responsibly in relation to the constitutional domain. It argues that in place of the "Hardball" politics that operates during ordinary political skirmishes, Special Norms appropriately apply to Congress when it engages in constitutional decisionmaking. ${ }^{109}$ The Special Norms include a cluster of attitudinal and substantive guidelines that facilitate responsible action, including a disposition to achieve consensus through persuasion and compromise. ${ }^{110}$ So even though Congress may not generally function as a responsible constitutional decisionmaker at present, it would be a mistake to assume this to be a fixed and permanent feature of our political life. ${ }^{111}$ Although the Self-Defeating Proposal Objection raises important concerns, it is hardly the final word on the matter.

105. See supra note 101 and accompanying text.

106. See supra notes 25-26 and accompanying text.

107. See supra Parts I-II.

108. See supra Parts I-II.

109. See Rosen, supra note 41 at 62.

110. See id. at 5.

111. See Brest, supra note 39. 